\title{
An Analysis of the Characters in The Heart Is a Lonely Hunter
}

\author{
Yang Zhao
}

Foreign Languages College, Beihua University, Jilin 132013, China.

Keywords: The Heart Is a Lonely Hunter, Character Analysis, Loneliness

\begin{abstract}
Carson McCullers has been considered as one of the most influential American southern women writers in the $20^{\text {th }}$ century. Her first novel The Heart Is a Lonely Hunter is a spiritual presentation of the Southern Americans against the background of American South in the 1930s, the time between the Great Depression and the Second World. In this novel, McCullers told a desperately sad story about the deaf-mute Singer, his deaf-mute friend Antonatoulos and his four friends, who are the little girl Mick, the black doctor Copeland, the drunken Jake and the observer Biff. The characters in this novel share a common feature: loneliness.
\end{abstract}

\section{Introduction}

Carson McCullers is a typical representative of the important writers of America in the $20^{\text {th }}$ century. The Heart Is a Lonely Hunter is one of her representative novels. She suffers from the pains of the illness in her whole life and at the same time nourishes by the south of America, which is probably why she loves writing the loneliness, separation and estrangement of the southern people in all her works. Limited as her works are, each of them can tell the story of marginalized individuals and picture human loneliness in the most ordinary language. She is regarded as one of the most important southern writers.

\section{John Singer}

Singer is in the center, and he is the most touching character in this novel. He is faithful and considerate, whose grayish green eyes naturally give off believable gentle light, so he easily comes into Mick's “inside room", and also becomes a good listener of everyone, "for they felt that the mute would always understood whatever they wanted to say to him. Taking a productive way to love, Singer realizes the relatedness to others. He would be the happiest man in the town if Antonapoulos shows the same affection for him. However, the relationship between Singer and Antonapoulos is more about Singer's one-side wish and idealistic satisfaction. The former softens his heart and soul while the latter is dependent on spiritual love and constantly asking for material. The unavoidable consequence is losing each other because of fruitless effort. All of these are the causes of loneliness, and all of these are the result of loneliness. As people of the same kind, they depend on each other, but they fail to fully communicate; as disabled men, they taste the bitterness of solitude.

Singer embodies the deepest loneliness and sorrow. His loneliness is also all the people's loneliness, and his relationship with Antonapoulos is the portrayal of the relationship of all the characters. Singer is "God" of little girl Mick, the gentle white man in Copeland's eyes and the biggest shoulder of all the people. Those lonely people come to Singer's room from time to time when Singer takes the visit to Antonapoulos as a happy journey. They are firmly convinced that Singer's silence and smile contain the greatest understanding of themselves. In Singer's heart, however, their coming merely take away a little bit of his loneliness. He thinks of Doctor Copeland, Mick, Jake Blout and Biff Brannon when he leaves the town and goes into the journey to visit Antonapoulos. "And Mick, her face was urgent and she said a good deal that he did not understand in the least...And strangers who followed him about the streets and buttonholed him for unexplainable reasons." As reaction to these people's causeless trust and dependence, Singer shows nothing but politeness and sympathy. His leaving without a word every time is an indication of the fact that the spiritual reflection they expect from him is vanishing into thin air. The coffee shop 
owner Biff is eventually aware of their one-sided wish at the end of this novel and "the mystery of Singer” remains unsolved. In this novel, McCullers lets the mute Singer become the core of the pyramid of loneliness, and when Singer sends out a lonely sense, he also absorbs others' loneliness. The wordless Singer “narrates” all people’s loneliness in a more profound way.

\section{Mick Kelly}

Critics point out that Mick represents McCullers herself and serves as a lens for the reader. Mick's first appearance in The Heart Is a Lonely Hunter is in Biff's coffee shop: “A gangling, towheaded youngster, a girl of twelve, stood looking in the doorway. She was dressed in khaki shorts, a blue shirt, and tennis shoes so that at first sight she was like a very young boy." Mick is a tomboy with an inner secret that she hopes to become a great musician of global renown and believes music is incomparable, "Sometimes this fellow's music was like little colorful pieces of crystal candy, and other times it was the softest, saddest thing she had ever imagined about." In order to taste music, she is always hiding in the night under the window of the rich family whose radios are magic box of some wonderful music. Eager for a secret garden of her own, she divides her inner world into "inside room" and "outside room”. Undoubtedly, Beethoven and Mozart are permanent melodies in her "inside room".

As the author refers when Mick first appears, she is a tomboy and she wants to be a boy. Climbing to the roof of a new house instead of trying to remain gentle and beautiful in a traditional sense like her two elder sisters is her meaning of life. Brave and rebellious, she writes some dirty words down on the wall with the initials of her name beneath every word. Loneliness steps into her heart as a result of lack of communication with others. She wants to fly like a bird, "she spread out her arms like wings," yet she just can't. She finds that "how lonesome a person could be in a crowded house," and she wishes to have a private place to study music, but she knows there is no place for her to go. It seems that all the noise outside has little relation to her. Her dream is gradually fading.

Then she holds a party with careful preparation. Although it doesn't go as she expects, little Mick feels her change right after that party. She suddenly realizes the growth of herself and knows that she can't be a tomboy any more, and she should return to what a real female is supposed to be. "She was too big to wear shorts any more after this. No more after this night. Not anymore." The next day, she has an adventurous date with Harry. Deep in the woods, and they have played in the pool for nearly two hours. Then Mick proposes the idea of naked swimming. They have been faced with each other's naked body for only a while, "Maybe it was half an hour they stood there maybe not more than a minute." After lunch, they lie beside and naturally, like Adam and Eve, they kiss. In great fear, Harry leaves to another city, and Mick always feels the terror, "A queer afraid came to her. It was like the ceiling was slowly pressing down towards her face.”

Although Singer is undoubtedly the leading character in this novel, it can't be denied that Mick is also a remarkable role. To realize her "need for relatedness", she first seeks comfort from Singer who she thinks can understand her and thus they can establish a kind of connection; then she yields to reality and gives up her dream of music. She successfully becomes a part of the world she once hated and steps on the "normal" road of a woman. She turns to be a mediocre salesgirl and at the same time falls into the inescapable abyss of loneliness.

\section{Dr. Copeland}

Racism is a universal belief in the south where the white race thinks that the black people must obey them because they are more superior than the black. Copeland is an idealistic black physician in this southern town who devotes himself to improving the position of the oppressed black people in the town. His deep awareness of the condition of the black in the south gives him a lot of strength. Dr. Copeland wants to change this situation thus goes from one black man's house to another to offer them medical help everyday, which provides him with the opportunity to spread his ideas and wishes to arouse people's awareness of rebellion. "All of his life he knew that there was a reason for 
his working. He always knew that he was meant to teach his people. All day he would go with his bag from house to house and on all things he would talk to them." However, for some reason the black people can't understand his purpose of saving the whole race and his efforts to help them and he fails to enlighten them. What's worse, his family is broken because he is absorbed in his career and doesn't give his wife and children the concern they need.

Dr. Copeland loves his wife, which is undoubted. They are separated from each other; however, for they both don't have real communication because they hold their own ideas on life firmly. When Copeland talks about his mission again and again, she agrees with him because she is a kind and gentle woman. Unlike Copeland, she is born with obedience. So there is a huge gap between them. Copeland can't get the support from his wife therefore he feels isolated and finally treats his wife with violence which in the end leads to their separation. Meanwhile, his children are afraid of him and separate from him too. His daughter Portia, the only one of his children who will come to his house and talk to him, knows clearly that her brothers all are afraid of Copeland and don't want to talk to him. They all like their gentle mother, who treats them like the normal children and gives them freedom to do things they like. Their father, on the contrary, incessantly forces them to accept his idea that the responsibility of them is to save the whole Negro race. Although his four children won't listen to their serious father, Copeland will repeat this over and over again. Copeland feels lonely and desperately, realizing that no one can help him to realize his dream because none of his children grow according to his plan.

Then he meets Singer. It is a rainy night when he comes back from delivering a baby. Without an umbrella, he is standing in the street corner with a unlighted cigarette between fingers. He wants to light the cigarette but fails for several times. At that time, a white man comes to him and passes him a lighted one. "In the dark with the flame between them they could see each other's faces." It is then that he feels this white man being different from others and thinks this mysterious gentleman can understand his holy purpose. For Copeland, Singer is such a helper with magic atmosphere and he even regards Singer as a man like God. Since Singer is a mute, Copeland thinks that he can put all his wishes on him and make him a perfect man like God according to his imagination. He is satisfied with the fact that some characters that are meant to only belong to the oppressed race can be found on Singer, the person who he thinks can understands him clearly. However, he is wrong. The reason that Singer always listens to him and smiles to him is only because of his politeness and loneliness. When Singer shoots himself to death, Copeland feels very sad. The mystery of Singer's suicide makes him perplexed and helpless. "There was neither beginning nor end to this sorrow. Nor understanding."

Copeland has lost too much in order to realize his dream. He does have a big family with four children at first, but he lives alone in his big house in the end. His wife leaves him and dies early, his children separate from him and they seldom meet each other, and then the only one who he trusts commits suicide regardless of his bad situation. What life leaves him is only loneliness and sadness.

\section{Summary}

Carson McCullers, in her short and unfortunate life, creates plenty of excellent works, in which she endeavors to express her earnest concern about the South and to present the spiritual crisis of the southerners. Universally acknowledged as one of McCullers' best novels, The Heart Is a Lonely Hunter discloses almost all problems the American southern states faced in the early twentieth century under the influence of various kinds of objective elements and manifests the author's unique writing arts.

In The Heart Is a Lonely Hunter, McCullers leads us to experience a journey of complex sensations and discloses the intense racism and loneliness lingering in the American South of the early twentieth century. The author precisely records how severe racism brings common black people miseries and mishaps and how the black intellectuals make every effort to awaken the numb black public. Another perplexing problem that the author tries to reveal is the spiritual loneliness of the southerners. With the rapid development of capitalism, a great variety of new ideologies poured 
in and people in the southern mill town become alienated and disorientated, thus getting stuck in severe spiritual crisis. The themes of haunting loneliness actually add colors and inject essences to this great work.

This paper, aimed at a tentative exploration of Carson McCullers' The Heart Is a Lonely Hunter, makes sense in the following two aspects: firstly, it enables us to have a good grip of the three representative figures: the mute Singer, the tomboy Mick and the African American Copeland; secondly, it reveals a tentative exploration of the social factors that contribute to the common feature of three figures-loneliness: identity boundary and the diminishing of the role of god. By means of an analysis under the southern historical and cultural context, the author's sincere concern for her beloved south will be more widely empathetic.

\section{References}

[1] Carson McCullers. The Flowering Dream: Notes on Writing [J]. Esquire, LII, 1959, (12).

[2] Presley Delma Eugene. Carson McCullers and the South [J].The Georgia Review, 1974, (03).

[3] Rubinstein, Annette T.. American Literature Root and Flower [M]. Foreign Language Teaching and Research Press, 1998. 